\title{
PREDICTION OF GAS EMISSION AND DERIVED ELECTRICAL POWER GENERATION FROM SHIRAZ LANDFILL
}

\author{
FARZADKIA M. ${ }^{1}$ \\ DJAHED B. ${ }^{2, *}$ \\ SHAHSAVANI S. ${ }^{3}$ \\ DEHGHANIFARD E. ${ }^{4}$
}

\author{
${ }^{1}$ Department of Environmental Health Engineering, School of Public Health \\ Iran University of Medical Sciences, Tehran, Iran \\ ${ }^{2}$ Department of Environmental Health Engineering \\ Iranshahr University of Medical Sciences, Iranshahr, Iran \\ ${ }^{3}$ Department of Environmental Health Engineering, School of Public Health \\ Shiraz University of Medical Sciences, Shiraz, Iran \\ ${ }^{4}$ Department of Environmental Health Engineering, School of Public Health \\ Alborz University of Medical Sciences, Karaj, Iran
}

Received: 05/01/2014

Accepted: $12 / 05 / 2015$

Available online: $24 / 06 / 2015$

*to whom all correspondence should be addressed: e-mail: Babak.Djahed@gmail.com

\begin{abstract}
Landfilling has been considered as the most common method for solid waste disposal in developing countries which is faced with several issues, such as gas emission. Methane as a greenhouse gas is the main landfill gas which could be applied as a fuel for electrical power plants. In this study, the gas emission of Shiraz landfill site was predicted by using USEPA model, for this purpose, after determination of the solid waste physical composition on Shiraz landfill site, the $L_{0}$ and $k$ constants were estimated by Monte Carlo method, as well as the rate of gas collection and the rate of electrical power generation capacity were estimated under existing and ideal scenarios. The results showed that gas production would reach its peak up to $5.7 \times 10^{7} \mathrm{~m}^{3}$ year-1 by 2039 . The maximum electrical power generation was also similar to the pattern of gas production in the landfill and would be $2545 \mathrm{GWh}$ and 4019GWh for the existing and ideal conditions, respectively in 2039. Results showed that the recovery of biogas at Shiraz landfill could be a desirable alternative in different available waste management options for this city.
\end{abstract}

Keywords: Solid waste, Landfill, Greenhouse gas, Electrical power, Shiraz

\section{Introduction}

Nowadays, generation of solid waste has been increased due to the socio-economical developments in the developed countries and increase of population in the developing countries (Czepiel et al., 2003; Park and Shin, 2001), hence this situation causes an increasing environmental concern about disposal of municipal solid waste in all over the world (Salehi et al., 2011). Landfilling is one of the most common methods for disposal of the municipal solid wastes which avoids separation, recovery, and incineration processes from these valuable materials (Desideri, 2003, Park and Shin, 2001). It is estimated that about 1.5 billion tons of the produced solid wastes in the world are annually buried in landfills (Themelis and Ulloa 2007). However, Landfilling usually leads to secondary pollutions, such as surface and ground water contamination by leachate, and also causes air pollution by emitting unpleasant odors produced from decomposition of organic materials (Park and Shin, 2001; Tsatsarelis and Karagiannidis, 2009; Zamorano et al., 2007). During the biological processing in degradation of organic wastes, methane, carbon dioxide, and other trace gases could be emitted from landfills and gas generation may be continued up to 30-100 
years (Faour et al., 2007; Zamorano et al., 2007). One of the main components of landfill gas (LFG) is methane (40-70\%) (Bicheldey and Latushkina 2010; Ozcan et al. 2007). Due to the molecular structure and stability of methane in the atmosphere (about 9 years), the global warming effect of this gas is about 20-25 times more than carbon dioxide (Ozcan et al. 2007; Park and Shin, 2001; Zamorano et al., 2007). Studies showed that 3-19\% of total global emissions of methane which was about 40Tg year ${ }^{-1}$ was produced in the landfills (Ozcan et al., 2007, Park and Shin, 2001, Wang-Yao et al., 2006, Zamorano et al., 2007) and this amount comprises about 10-19\% of anthropogenic methane emissions (Stern et al., 2007). By using the methane gas in the landfills, we can reduce its greenhouse effects and also obtain a renewable source of energy (Machado et al., 2009; Park and Shin, 2001, Wang-Yao et al., 2006, Zamorano et al., 2007). Based on the previous studies, about $83.56 \%$ ( 8666001.56 tons year ${ }^{-1}$ ) of the produced solid wastes in Iran are disposed using the landfilling method (Nabizadeh et al., 2008). This rate of buried solid wastes could lead to the production of large amounts of methane gas which is estimated to be about 0.3 million tons per year (Farzadkia et al., 2011b); hence, it could be an enormous source of fuel for power plants and using this produced LFG in the power plants installed close to the landfill could be considered as the best option. Evaluation of methane generation in the landfills is the first step and the most important factor for construction of these types of power plants (Machado et al., 2009). Therefore, the present study aims to evaluate methane gas generation in Shiraz landfill and predict the appropriate capacity of its electrical power plant.

\subsection{Site specifications}

Shiraz is the capital of Fars province which is located in south of Iran. In the last population census, the population of Shiraz was estimated about 1,200,000 individuals making it the sixth largest city of Iran. In 1997, 20 hectares of Shiraz public lands were allocated for Shiraz's solid waste landfilling. It is anticipated that this landfill will respond to all the city's needs for 40 years. In this site, the rate of solid waste burial, which is performed daily and continuously through area-tranche method, is about 900 ton day ${ }^{-1}$. The length, width, and depth of tranches in this landfill are about 800,100 , and $16 \mathrm{~m}$, respectively. Besides, each layer of this landfill is $8 \mathrm{~m}$ and after each layer, it is covered by $1 \mathrm{~m}$ of soil. In order to collect the produced LFG from trenches, some perforated pipes were vertically planted inside the buried solid waste rows which were connected to a main pipe with the capacity of $840 \mathrm{~m}^{3} \mathrm{~h}^{-1}$ transferring the collected LFG to a 7.71MWh year-1 electrical power plant. The Geographical location of Shiraz landfill is depicted in Fig.1.

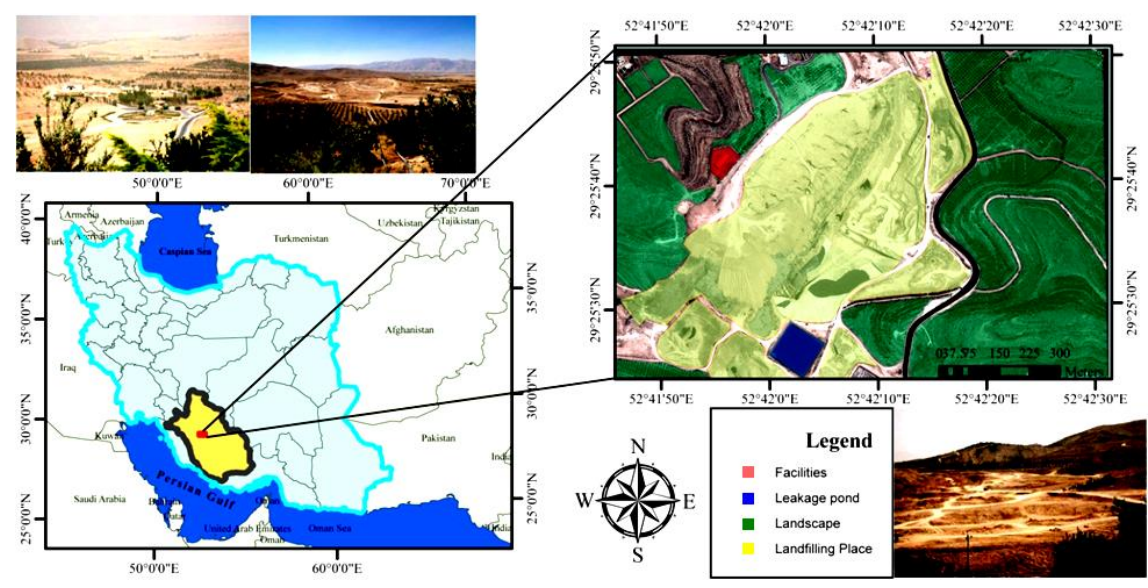

Figure 1. Geographical location of Shiraz Landfill

\section{Materials and Methods}

\subsection{Solid waste physical composition}

To achieve the exact and real physical composition of Shiraz municipal solid waste, we collected and analyzed 12 samples of solid wastes, which gathered at the landfill site during 4 periods (half of each 
season). By a hand-sorting procedure, the gravimetric composition of the waste was determined into 8 separate categories (food waste, paper and cardboard, textiles, yard waste, metals, glass, plastics, other materials). Also the water content of the gathered samples was determined using the wet-weight method. For this purpose approximately $0.5-1 \mathrm{~kg}$ waste sample was placed in an oven at $105{ }^{\circ} \mathrm{C}$ until a constant weight achieved.

\subsection{Methane emission modeling}

The rate of biogas production could be estimated by different methods, some of which are based on the equations which require the composition of solid waste. Besides, the experiences obtained from completely controlled environments are used in some methods. In some other models, on the other hand, the data obtained from field measurements are used (Bicheldey and Latushkina, 2010; Tsatsarelis and Karagiannidis, 2009; Wang-Yao et al., 2006; Zamorano et al., 2007). Some models for predicting the biogas production rate are illustrated in Table1.

Table 1. Some models for estimation of methane emission from landfills (Kamalan et al., 2011, Thompson et al., 2009; Farzadkia et al., 2011b)

\begin{tabular}{c|c|c}
\hline Name of model & Model & Comment \\
\hline EPER Germany & $\mathrm{M}_{\mathrm{e}}=\mathrm{M} \times \mathrm{BDC} \times \mathrm{BDC}_{\mathrm{f}} \times \mathrm{F} \times \mathrm{D} \times \mathrm{C}$ & Zero Order \\
\hline SWANA & $\mathrm{Q}=\mathrm{ML}_{0} / \mathrm{t}_{0}-\mathrm{t}_{1}$ & Zero Order \\
\hline IPCC & $Q=\left(\mathrm{MSWT} \times \mathrm{MSWF} \times \mathrm{MCF} \times \mathrm{DOC} \times \mathrm{DOC} C_{\mathrm{f}} \times \mathrm{F} \times(16 / 12)-\mathrm{R}\right) \times(1-\mathrm{OX})$ & Zero Order \\
\hline SWANA & $\mathrm{Q}=\mathrm{ML}_{0} \mathrm{e}^{-\mathrm{kt}}$ & First Order \\
\hline TNO & $\alpha_{\mathrm{t}}=\zeta 1.87 \mathrm{CC}_{0} \mathrm{~K}_{\mathrm{l}} \mathrm{e}^{-\mathrm{k}_{\mathrm{l}} \mathrm{t}}$ & First Order \\
\hline Land GEM & $\mathrm{Q}_{\mathrm{CH}_{4}}=\sum_{\mathrm{i}=1}^{\mathrm{n}} \mathrm{k}_{\mathrm{L}_{0}} \mathrm{M}_{\mathrm{i}}\left(\mathrm{e}^{-\mathrm{kt}_{\mathrm{i}}}\right)$ & First Order \\
\hline
\end{tabular}

${ }^{*}$ The equation used in the present study.

The first order decay model (Eq.1) is the most useful one which is recommended by IPCC and USEPA (IPCC 2006; US-EPA 2005a); therefore, this model was used in the present study in order to estimate the rate of biogas production of Shiraz landfill.

$$
\mathrm{Q}=\sum_{\mathrm{i}=1}^{\mathrm{n}} \mathrm{k}_{0} \mathrm{M}_{\mathrm{i}} \mathrm{e}^{-k \mathrm{t}_{i}}
$$

In this model, $\mathrm{Q}\left(\mathrm{m}^{3}\right.$ year $\left.^{-1}\right)$ is annual methane generation in the year of calculation, $\mathrm{k}\left(\mathrm{year}^{-1}\right)$ is methane generation rate constant, $\mathrm{M}_{\mathrm{i}}$ (years) is weight of the accepted waste in the $\mathrm{i}^{\text {th }}$ year and $\mathrm{L}_{0}\left(\mathrm{~m}^{3} \mathrm{CH}_{4} \mathrm{Mg}^{-1}\right.$ of MSW) is potential methane generation capacity; the methods which used for estimation of $k, L_{0}$ and $M_{i}$, are explained in following.

\subsubsection{Estimation of $L_{0}$}

There are different models for estimation of $\mathrm{L}_{0}$ (Machado et al., 2009; Thompson et al., 2009); according to the available information and by considering the results of the study which Farzadkia et al., conducted on the estimation of methane production potential of waste buried in Iran (Farzadkia et al., 2011b), the revised IPCC model (Eq.2) was used to determine $\mathrm{L}_{0}$. In this model, $\mathrm{L}_{0}\left(\mathrm{~m}^{3} \mathrm{CH}_{4} \mathrm{Mg}^{-1}\right.$ of $\left.\mathrm{MSW}\right)$ is determined through a mass balance approach that contains the determination of the degradable organic carbon content of the waste.

$$
\mathrm{L}_{0}=\frac{\mathrm{F}_{\mathrm{CH}_{4}} \times M C F \times \frac{16}{12} \times\left(\sum_{\mathrm{i}=1}^{\mathrm{n}} \mathrm{DOC}_{\mathrm{i}} \times \mathrm{DOC}_{\mathrm{f}_{\mathrm{i}}} \times \mathrm{FR}_{\mathrm{i}}\right)}{\rho_{\mathrm{CH}_{4}}(1+\mathrm{w})}
$$

In Eq.2, the $\mathrm{F}_{\mathrm{CH} 4}$ is the percentage of the $\mathrm{CH}_{4}$ volume concentration, MCF (unit less) is a correction factor, $\mathrm{DOC}_{\mathrm{i}}(\%)$ is the degradable organic carbon content in $\mathrm{i}^{\text {th }}$ constituent of solid waste, $\mathrm{DOC}_{\mathrm{fi}}(\%)$ is a portion of $D O C_{i}$ that degraded and converted to the gaseous form and ultimately released from landfill, $F R_{i}(\%)$ is 
the portion of each component in the waste composition, $\rho_{\mathrm{CH} 4}\left(\mathrm{~kg} \mathrm{~m}^{-3}\right)$ is the density of methane $(0.717$ $\mathrm{kg} \mathrm{m}^{-3}$ ) and $\mathrm{w}(\%)$ is the water content of the waste. The parameters of $\mathrm{DOC}_{\mathrm{i}}$ and $\mathrm{DOC}_{\mathrm{f}}$ for different constituents of Shiraz solid waste are estimated using Table 2 . Besides, The $\mathrm{F}_{\mathrm{CH} 4}$ was selected between 50$60 \%$; the selection of this range was based on literatures and previous studies (Omrani et al., 2008; Tchobanoglous et al., 1993; Pichtel, 2005). The correction factor of MCF shows a portion of the waste which decomposes under aerobic condition prior switching of landfill to anaerobic condition, considering the high deep of the studied landfill, the value of this parameter was selected between 0.8-1 (Table 2). Also the coefficient of $16 / 12$ in this model is molecular weight ratio of $\mathrm{CH}_{4}$ and $\mathrm{C}$.

Table 2. Correction factor for methane, fraction of degradable organic carbon and biodegradable carbon (Machado et al., 2009; Farzadkia et al., 2011b)

\begin{tabular}{c|c|c|cc}
\hline \multicolumn{2}{c|}{ Correction factor for methane } & \multicolumn{3}{c}{$\begin{array}{c}\text { Fraction of degradable organic carbon and } \\
\text { biodegradable carbon }\end{array}$} \\
\hline Type of landfill site & MCF & Type of waste & DOC (\%) & $(\%) D O C_{f}$ \\
\hline Managed-anaerobic & 1.0 & $\begin{array}{c}\text { Paper and } \\
\text { paperboard }\end{array}$ & 100 & 35 \\
\hline Managed-semi-aerobic & 0.5 & Food waste & 100 & 75 \\
\hline $\begin{array}{c}\text { Unmanaged-deep(>5m waste) } \\
\text { and /or high water table }\end{array}$ & 0.8 & Yard waste & 100 & 30 \\
\hline $\begin{array}{c}\text { Unmanaged -shallow (<5m } \\
\text { waste) }\end{array}$ & 0.4 & Textiles & 50 & - \\
\hline Uncategorized landfill & 0.6 & - & - & \\
\hline
\end{tabular}

\subsubsection{Estimation of $k$}

In determining the methane generation rate in the landfills, another important kinetic factor is the methane generation rate constant $(k)$, in present study, the value of $k$ was determined by considering Table 3 and Eq. 3.

$$
k=\frac{\sum_{i=1}^{n} k_{i} F R_{i}}{\sum_{i=1}^{n} F R_{i}}
$$

In Eq. 3, the $k_{i}$ (unit less) is the methane generation rate constant for each fraction of solid waste and considering the dry and temperate climate of Shiraz city, the range of this parameter was selected from table 3. Also the $\mathrm{FR}_{\mathrm{i}}(\%)$ is the fraction of each component in the solid waste.

\subsubsection{Estimation of $M_{i}$}

One of the parameters in model 2 is the waste buried in the $\mathrm{i}^{\text {th }}$ year. The data on the rate of buried waste were available from 1997 to 2013, and Eq.4 was used in order to calculate the rate of waste buried until the end of landfill life in 2037.

$$
\mathrm{P}_{\mathrm{i}}=\mathrm{P}_{0}(1+\alpha)^{\mathrm{i}}
$$

In Eq.4, the $\mathrm{P}_{\mathrm{i}}$ is Population in the $\mathrm{i}^{\text {th }}$ year, the $\mathrm{P}_{0}$ is Population in the current year and $\alpha$ is Population growth rate. The rate of the population growth was selected as $1.5 \%$ and with respect to the solid waste minimization policy and due to good market exist in Iran for recycled materials (Farzadkia et al. 2011a), the rate of waste production per capita was considered as $700 \mathrm{gr}$ constantly in all years. The calculated population rate in the ith year was multiplied by the rate of waste production per capita (700 gr) to determine the waste buried in the ith year. 
Table 3. The values of k recommended by IPCC 2006 (Machado et al., 2009; Wangyao et al., 2010)

\begin{tabular}{|c|c|c|c|c|c|c|c|c|c|}
\hline \multirow{2}{*}{\multicolumn{2}{|c|}{ Type of waste }} & \multicolumn{2}{|c|}{$\begin{array}{c}\text { Dry boreal and } \\
\text { temperate } \\
\text { Climate }\end{array}$} & \multicolumn{2}{|c|}{$\begin{array}{l}\text { Wet boreal and } \\
\text { temperate } \\
\text { climate }\end{array}$} & \multicolumn{2}{|c|}{ Dry tropical climate } & \multicolumn{2}{|c|}{ Wet tropical climate } \\
\hline & & Default & Range & Default & Range & Default & Range & Default & Range \\
\hline \multirow{2}{*}{$\begin{array}{l}\text { Slowly } \\
\text { degrading } \\
\text { waste }\end{array}$} & Paper/textiles waste & 0.04 & $0.03-0.05$ & 0.06 & $0.05-0.07$ & 0.045 & $0.04-0.06$ & 0.07 & $0.085-0.06$ \\
\hline & Wood/straw waste & 0.02 & $0.01-0.03$ & 0.03 & $0.02-0.04$ & 0.025 & $0.04-0.02$ & 0.035 & $0.05-0.03$ \\
\hline $\begin{array}{c}\text { Moderately } \\
\text { degrading } \\
\text { waste }\end{array}$ & $\begin{array}{c}\text { Other (non-food) organic } \\
\text { putrescible/garden and } \\
\text { park waste }\end{array}$ & 0.05 & $0.06-0.04$ & 0.1 & $0.1-0.06$ & 0.065 & $0.08-0.05$ & 0.17 & $0.2-0.15$ \\
\hline $\begin{array}{l}\text { Rapidly } \\
\text { degrading } \\
\text { waste }\end{array}$ & Food waste/sewage sludge & 0.06 & $0.08-0.05$ & 0.185 & $0.1-0.2$ & .0085 & $0.1-0.07$ & 0.4 & $0.7-0.17$ \\
\hline Bulk waste & - & 0.05 & $0.06-0.04$ & 0.09 & $0.1-0.08$ & 0.065 & $0.08-0.05$ & 0.17 & $0.2-0.15$ \\
\hline
\end{tabular}




\subsection{Electrical power generation}

In order to estimate the capacity of electrical power plant, two scenarios were defined for efficiency of the LFG collection system in Shiraz landfill. The first scenario estimated the efficiency of the LFG collection system in the existing condition of the landfill. In doing so, the efficiency rate of the collection system was calculated by using the Mexico Landfill Gas model version 2.0. In the second scenario (ideal scenario), the efficiency rate of the gas collection system was selected in accordance with the IPCC recommendation; based on these scenarios, the rate of gas collection was calculated in both the existing and ideal conditions. In comparison to natural gas with $37.25 \mathrm{MJ} \mathrm{m}^{-3}$, LFG with 15-19 $\mathrm{MJ} \mathrm{m}^{-3}$ energy content has a low heating value; therefore, by assuming $3.605 \mathrm{MJ} \mathrm{KWh}^{-1}$ for mechanical equivalent, if the overall system efficiency be $20 \%$, the conversion rate will be $18.004 \mathrm{MJ} \mathrm{KWh}^{-1}$. The electrical energy production was calculated through Eq.5 (Tchobanoglous et al., 1993).

$$
\text { Electrical energy production }(K W h)=\frac{\text { fuel Thermal energy }(J)}{\text { Heat exchange rate }\left(\frac{\mathrm{J}}{\mathrm{KWh}}\right)}
$$

Finally, by assuming the use of $1 \mathrm{MW}$ generators, the appropriate capacity of electrical power plant was determined in ideal and existing conditions.

\subsection{Uncertainty Analysis}

The input value of parameters in model 2 and 3 are the field averages or they are estimates from previous studies that could be included a range of values, this situation shows that the expected coefficient of $L_{0}$ and $\mathrm{k}$ for this landfill could not be a deterministic value, and it is associated with uncertainty, hence in these cases the uncertainty analysis is essential. When uncertainties are large or probability distribution is non-Gaussian, the numerical statistical techniques like Monte Carlo are suitable for estimating uncertainty in emission factor (IPCC 2000). Monte Carlo simulation is a method that uses random numbers in input parameters to identify the stochastic behavior of the model and it shows the extreme possibilities along with all possible consequences. In present study @Model Risk software version 5.0.2.1 was used to perform the Monte Carlo simulation. For this simulation, the probability distribution of $\mathrm{F}_{\mathrm{CH} 4}$ was selected uniform and for $\mathrm{K}_{\mathrm{i}}, \mathrm{MCF}$ and $\mathrm{DOC}$, the triangle distribution was utilized, also for $\mathrm{W}$ and $F \mathrm{R}_{\mathrm{i}}$ parameters the normal distribution were selected. 50000 iterations were used to perform mentioned simulation.

\section{Results and Discussion}

The physical analysis of Shiraz solid waste indicated that the food waste is dominated fraction; also, as shown in Fig. 2, the categories of plastics and papers are the other major constituents. These results show that the organic fractions of Shiraz solid waste are high significantly. Also the average water content of gathered samples were determined as $65.8 \pm 12.3$ percent.

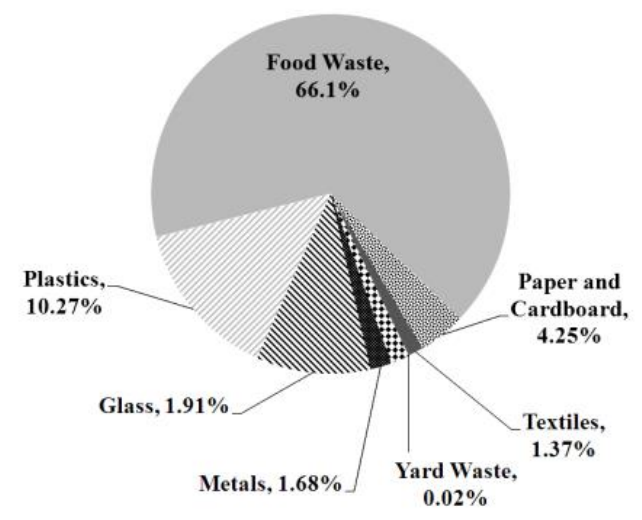

Figure 2. Physical composition of Shiraz solid waste (percent of mass) 
In the LandGem model, values of $\mathrm{L}_{0}$ and $\mathrm{k}$ are highly critical for determining the LFG generation (Zamorano et al., 2007). The probability distribution of $L_{0}$ and $k$ were determined by Monte Carlo simulation and the results are shown in Fig. 3 and 4. The effective parameters which influence the $L_{0}$ value are solid waste composition and the decomposable fraction of the organic material (Wang-Yao et al., 2006). The recommended amounts for $L_{0}$ in different sources are less than 100 to 270 cubic meters per each ton of the buried solid waste (Faour et al., 2007; Machado et al., 2009, US-EPA 2005b; Wang-Yao et al., 2006). Monte Carlo simulation showed that the minimum and maximum of $L_{0}$ in Shiraz landfill could be 57.25 and $304.75 \mathrm{~m}^{3}$ ton $^{-1}$ respectively, but as seen in Fig. 3 the most probable range of $\mathrm{L}_{0}$ is around $150 \mathrm{~m}^{3} / \mathrm{Mg}$, hence the mean of obtain distribution $(155.22 \pm 34.63)$ was considered as $L_{0}$. This measure is quite consistent with the results obtained in the studies conducted by Farzadkia et al. and Adl et al.; Farzadkia et al. reported $162.7 \mathrm{~m}^{3}$ LFG production per each ton of waste buried in Iran (Farzadkia et al. 2011b). In the other study on Shiraz municipal solid waste, Adl et al. calculated the rate of $L_{0}$ as about $143 \mathrm{~m}^{3}$ ton $^{-1}$ (Adl et al., 2005), which is close to the results obtained in the present study. The high $L_{0}$ obtained in this study is due to the high biodegradable fraction of solid waste buried in Shiraz landfill. For instance, Faour et al. (Faour et al., 2007) conducted a study on three landfills in the U.S. and calculated lower $L_{0}$ in comparison to present study $\left(115,95\right.$ and $87 \mathrm{~m}$ ton $\left.^{-1}\right)$. This difference might be due to the existence of lower organic materials in the U.S. municipal solid waste compared to Shiraz municipal waste.

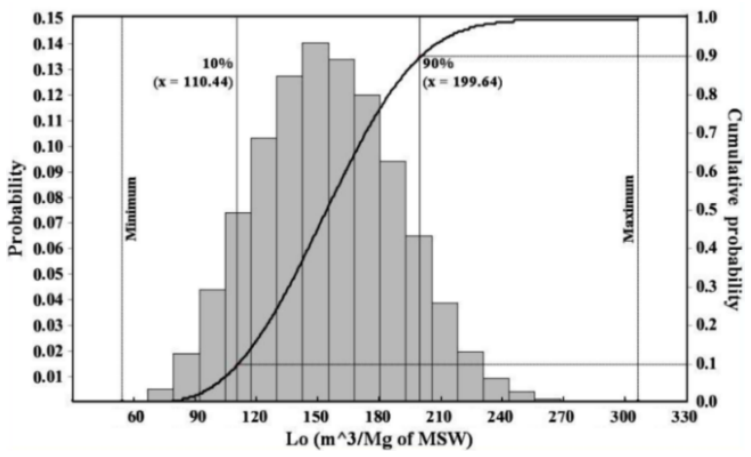

Figure 3. Probability distribution of Lo

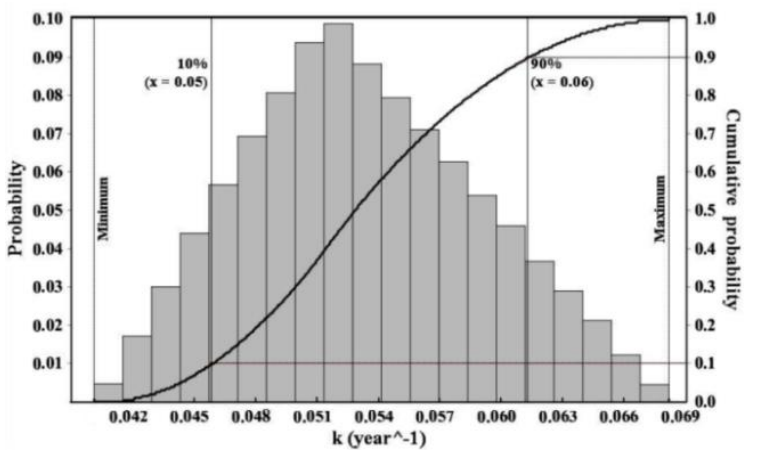

Figure 4. The probability distribution of $\mathrm{k}$

Methane generation rate constant $(\mathrm{k})$ is related to several factors, such as atmospheric precipitation, waste moisture content, $\mathrm{pH}$, temperature, and nutrients availability for methane producing microorganisms (Faour et al., 2007; Machado et al., 2009; US-EPA 2005b; Wang-Yao et al., 2006), and may range from 0.003 to 0.21 (US-EPA 2005b). As the rate of biodegradability, moisture of solid waste, and temperature of landfill site rises, the $k$ constant rises, as well. For instance, Wang-Yao et al. conducted a study in Thailand and due to the high fraction of organic materials which could rapidly become degraded, the high moisture content of the waste buried in this area, and the wet tropical climate in Thailand, they decided to take a high $\mathrm{k}$ value (0.15) for LFG estimation. Based on United States Clean Air Act (CAA), $k$ values of $0.05,0.02$, and 0.04 are recommended for sanitary landfills in arid regions and landfills having leachate recirculation. In the present study, the Monte Carlo simulation shows that the most probable range of $\mathrm{k}$ is approximately between 0.05 and 0.054 (Fig. 4); hence the mean of obtained distribution $(0.053 \pm 0.0057)$ was used as value of $k$. This value is consistent with the $k$ constant Omrani et al. (0.06) and Adl et al. (0.05) selected in their studies which were conducted on LFG production in Shiraz Landfill (Omrani et al., 2008; Adl et al., 2005).

In order to optimize the dimensions of a power plant fed by LFG, it is critical to quantify LFG production over several years. Therefore, biogas generation in Shiraz landfill was calculated by using the obtained $\mathrm{L}_{0}$ and $\mathrm{k}$ as well as Eq.1. In general, biogas production models assume the landfills as batch reactors in which anaerobic reaction is hypothesized as first order (Manna et al., 1999). Since the first order decay model applies the effect of age, it is most widely used for estimating the rate of LFG production (Mor et al., 2006) and it was used successfully for predicting the rate of methane gas emission in landfills in many studies, such as Faour et al., 2007; Machado et al., 2009; Wang-Yao et al., 2006; Zamorano et al., 2007. Also, Di 
Bella et al., 2011, showed this model to have a good agreement with the field measurements. Hence, the first order model (LandGem) proposed by USEPA was used in the present study in order to estimate the rate of biogas production of Shiraz landfill. Fig.5 shows the estimation rate of methane, LFG, and carbon dioxide gas generation between 1997and 2136 by the first order decay model. As demonstrated, methane gas generation and LFG production will reach their maximum rates by $2039\left(5.7 \times 10^{7} \mathrm{~m}^{3}\right.$ and $1.12 \times 10^{8} \mathrm{~m}^{3}$, respectively). Omrani et al., 2008, estimated the maximum methane generation $\left(1.5 \times 10^{6} \mathrm{~m}^{3}\right.$ year $\left.\mathrm{r}^{-1}\right)$ to occur in Shiraz landfill in 2021. The lower methane generation and year of maximum methane generation in that study might be due to the researchers' lower $L_{0}$ calculation and higher k selection. From 1997 that Shiraz landfill was opened to 2137 that the production and emission of LFG will be finished, the rates of methane, carbon dioxide, and the total generated gases in this landfill will be $2.3,2.4$, and 4.8 billion cubic meters, respectively. Hence, if we have no gas collection systems and gas recycling programs, averagely 34 million ton methane and carbon dioxide will be emitted to atmosphere through all the years the landfill is generating biogas (1998-2137).

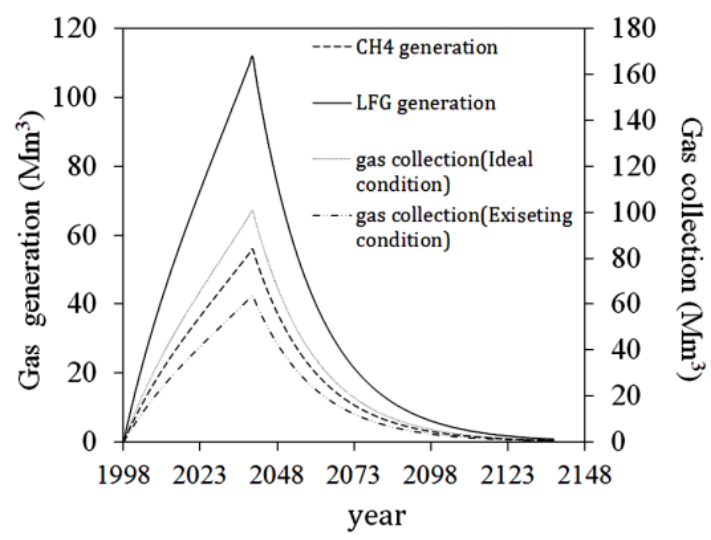

Figure 5. The rate of gas generation and gas collection from Shiraz landfill

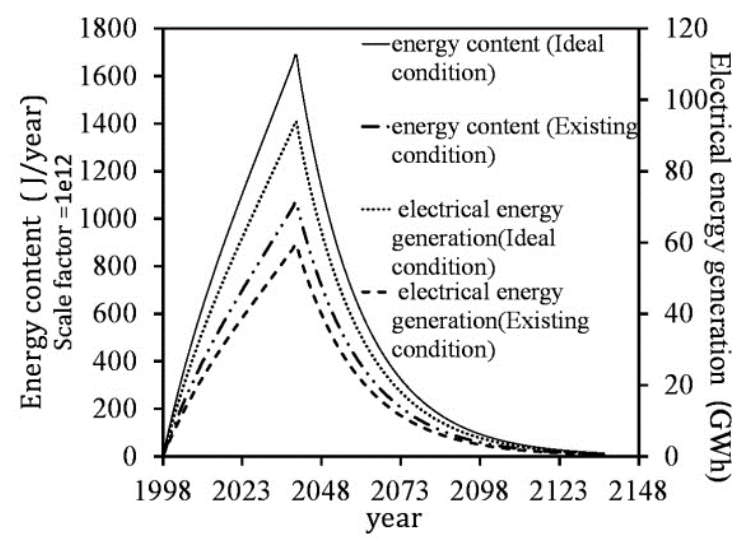

Figure 6. The energy content of the recovered biogas and the electrical energy generation of Shiraz landfill between 1997-2136

In fact, collection efficiency is defined as the percentage of the produced LFG in the landfill which is burned in flares or is restored for beneficial usages, such as electrical generation. Collection systems have a critical role in LFG to energy conversion process in many landfills because lack of LFG collection systems leads to the loss of a big fraction of the generated LFG which consequently, causes the emission of LFG to the atmosphere. For example, 25 landfills in California captured an average of $43 \mathrm{~m}^{3}$ methane per each ton of MSW and the rate of methane loss was estimated to be $82 \mathrm{~m}^{3}$ per each ton of MSW (Themelis and Ulloa 2007). Overall, more than $85 \%$ of the generated LFG can be restored in the landfills; of course, this number has been reported to be $90 \%$ in some cases. In unmanaged landfills, however, the maximum amount of this value has been estimated to be $50 \%$. Briefly, the effective factors influencing the rate of LFG recovery percentage are: 1 ) the area covered by the collection system, 2) depth of solid waste buried, 3) type of landfill coverage, 4) landfill bottom liner, and 5) waste compaction (US-EPA 2009b). Mexico Landfill Gas model is software which not only estimates the rate of gas generation from a landfill, but it also estimates the efficiency of the collection system in capturing the generated gas (Wang-Yao et al., 2006). According to the characteristics of Shiraz landfill (50\% area with collective wells, $100 \%$ area with final cover, $100 \%$ intermediate cover, $100 \%$ daily cover, and $0 \%$ bottom liner) and considering the leakage of leachate from the bottom to underneath layers, the efficiency of LFG collection system was estimated as $57 \%$ by this software. In addition, considering the ideal condition scenario, the efficiency of LFG collection system was selected as $90 \%$ based on IPCC recommendations.

As demonstrated in Fig.5, the first and the second scenarios were significantly different regarding the rate of the collected gas. In fact, the rate of the collected gas between 1997 and 2137 was calculated 1.4 and 
2.2 billion cubic meters in the existing and the ideal scenarios, respectively, which shows a difference of about 800 million cubic meters. Overall, having a plan for this amount of lost gas not only prevents the emissions of greenhouse gases and air pollution, but it will also have economic benefits. To achieve the ideal conditions, some measures, such as using bottom liners, subsurface and open drains systems, impermeable covers, increasing the depth of the landfill, and finally using vacuum systems for the generated LFG collection, are recommended.

By assuming $16.76 \mathrm{MJ} \mathrm{m}^{-3}$ energy content for LFG, it can be seen in Fig.6 that in both existing and ideal conditions, similar to the gas generation pattern, the maximum energy content will be in 2039 and then we will encounter a trend of decline until 2136. During the years that we will be encountered with gas generation, the total thermal energy content in both existing and ideal conditions will be $45.75 \times 10^{15}$ and $72.32 \times 10^{15} \mathrm{~J}$, respectively which seems to be very high.

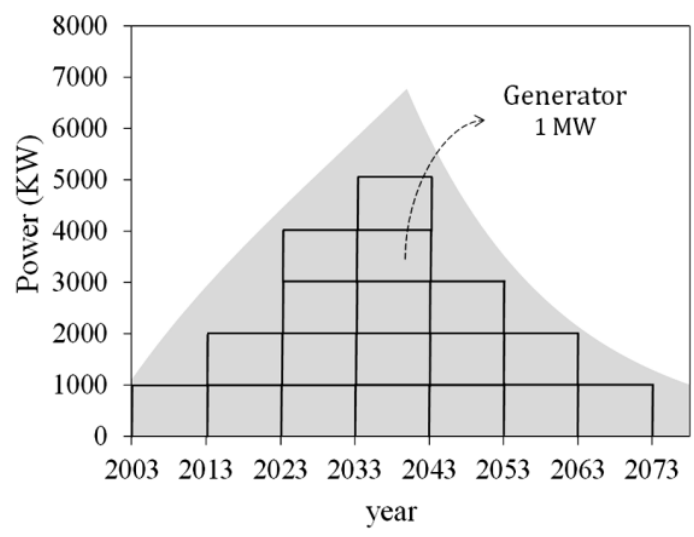

Figure 7. The number of the usable generators in the existing condition

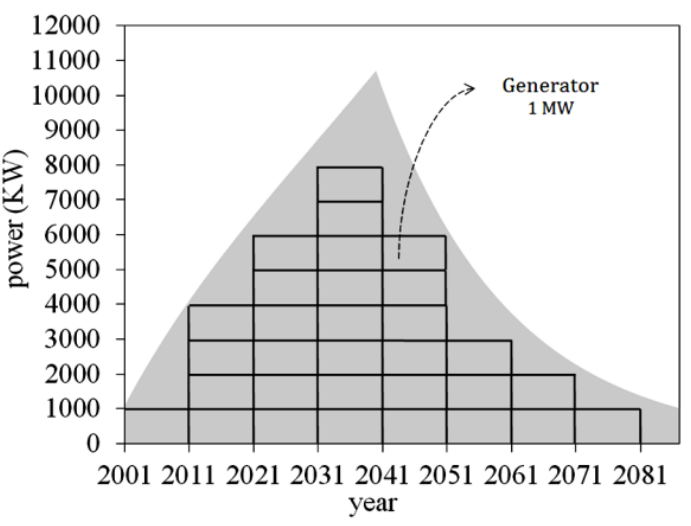

Figure 8. The number of the usable generators in the ideal condition

The rate of electrical energy produced from Shiraz landfill biogas was calculated according to $18004.5 \mathrm{KJ}$ $\mathrm{KWh}^{-1}$ thermal conversion rate (Fig.6). The maximum electrical energy generation is similar to the pattern of gas production in the landfill and will be $2545 \mathrm{GWh}$ and $4019 \mathrm{GWh}$ for the existing and ideal conditions, respectively in 2039 and will decline afterwards. Based on the rate of electrical energy consumption per capita of $2800 \mathrm{KWh}$ year $^{-1}$ (Sadeghi et al., 2011) and the average family size of about 4 people (Amini et al., 2009) in Iran, the maximum electrical energy in existing and ideal conditions provides 21236 (84945 people) and 33536 (134124 people) families' electrical demand, respectively.

The power of internal combustion engines for generating electricity from LFG varies from $800 \mathrm{~kW}$ to 3 MW (US-EPA 2009a). Assuming the utilize of $1 \mathrm{MW}$ generators and using each generators at full capacity, electrical energy production in existing and ideal conditions would begin in 2003 and 2001, respectively. As can be seen in Fig. 7 and 8, by using the $1 \mathrm{MW}$ generators and assuming 10 years for each generator's lifetime, the electrical energy generation could continue until 2073 and 2081 for existing and ideal conditions, respectively. Also, from 2031 to 2041 in the ideal condition and from 2033 to 2043 in the existing condition, the maximum number of the generators which could simultaneously be available will be 8 and 5 respectively. It should be noted that utilizing the generators with the power of less than $1 \mathrm{MW}$ could lead to a greater use of the produced gas from the landfill; however, due to an increase in the number of the generators in operation, it could lead to the increasing costs of system maintenance and operation. Eventually, in order to achieve the maximum efficiency and benefits, it is recommended to select the type of the generators by an economic analysis and considering the variables, such as costs per capita, costs operation and maintenance, tax, fuel prices, and profit gained from annual electricity selling. 


\section{Conclusions}

The present case study attempted to estimate the rate of LFG production in Shiraz landfill by first order model presented by USEPA. For this purpose the methane production potential and methane generation rate constant were estimated about $155.22 \mathrm{~m}^{3}$ year ${ }^{-1}$ and 0.053 respectively. Then by defining two scenarios (ideal and existing condition) for the LFG collecting system, the maximum generation of electrical energy from the collected LFG was estimated 2545GWh and 4019GWh for ideal and existing condition respectively. The results showed that further investment on the LFG collection system can significantly affect the collected LFG rate and subsequently influence the rate of the produced electrical energy. It seems that the recovery of biogas at Shiraz landfill could be a desirable alternative in different available waste management options for this city. On the other hand, utilizing of the LFG as a renewable energy at this site is not only economical, but it is also environmentally friendly.

\section{Acknowledgements}

We would like to thank Shiraz University of Medical Sciences for financial support of this research project. Hereby, the authors would like to thank the Municipality of Shiraz for their assistance in the research. Also, Research Improvement Center of Shiraz University of Medical Sciences and Ms. A. Keivanshekouh are appreciated for English editorial of manuscript.

\section{References}

Adl M.R. Godarzi-Rad, B. Boghlan-Dashti, S. Bozorgmehri and Lari H.R. (2005), Electrical Energy Generation Feasibility Study Results from Shiraz City Landfill. In 20th International Power System Conference. Tehran.

Amini R., Bafandekar A., Binai A., Peirovi A. and Khodamoradi M. (2009), Integrated waste management plan of Shiraz city. Shiraz: waste management organization of the Shiraz Municipality.

Bicheldey T.K. and Latushkina E.N. (2010), Biogass emission prognosis at the landfills, Int. J Environ. Sci. Tech, 7, 623-628.

Czepiel P.M., Shorter J.H., Mosher B., Allwine E., McManus J.B., Harriss R.C., Kolb C.E. and Lamb B.K. (2003), The influence of atmospheric pressure on landfill methane emissions, Waste management, 23, 593-598.

Desideri U. (2003), Sanitary landfill energetic potential analysis: a real case study, Energy Conversion and Management, 44, 1969-1981.

Di Bella G., Di Trapani D. and Viviani G. (2011), Evaluation of methane emissions from Palermo municipal landfill: Comparison between field measurements and models, Waste management, 31, 1820-1826.

Faour A.A., Reinhart D.R. and You H. (2007), First-order kinetic gas generation model parameters for wet landfills. Waste management, 27, 946-953.

Farzadkia M., Jorfi S., Akbari H. and Ghasemi M. (2011a), Evaluation of dry solid waste recycling from municipal solid waste: case of Mashhad city, Iran, Waste Management and Research, 30, 106-112.

Farzadkia M., Karimaee M. and Karami M.A. (2011b), Investigation of methane emission potential for municipal solid waste landfill sites in Iran and declining approaches 2008, Electronic Physician, 380-391.

IPCC. 2000. Good practice guidance and uncertainty management in national greenhouse gas inventories[available at www.ipcc-nggip.iges.or.jp/public/2006gl/vol1.html].

IPCC. 2006. Guidelines for national greenhouse gas inventories:Intergovermental panel on climate change Japan: IGES.

Kamalan H., Sabour M. and Shariatmadari N. (2011), A Review on Available Landfill Gas Models, Journal of Environmental Science and Technology, 2, 79-92.

Machado S.L., Carvalho M.F. and Gourc G.P. (2009), Methane generation in tropical landfills:simplified methods and field results, Waste management, 29, 153-161.

Manna L., Zanetti M.C. and Genon G. (1999), Modeling biogas production at landfill site, Resources, Conservation and recycling, 26, 1-14.

Mor S., Khaiwal R., De-Visscher A., Dahiya R.P. and Chandra A. (2006), Municipal Solid Waste Characterization and Its Assessment for Potential Methane Generation: A Case Study, Science of Total Environment, 371, 1-10. 
Nabizadeh R., Heidari M. and Hasanvand M.S. (2008), Municipal solid waste analysis in Iran, Iran. J. Health \& Environ, 1, 9-18.

Omrani G., Mohseni N., Haghighat K. and Javid A.H. (2008), Technical and health assessment of methane recovery from gas from Shiraz landfill, Journal of Environmental Sciences and Technology, 10, 174-182.

Ozcan H.K., Nemlioglu S. and Demir G. (2007), Methan emission in landfill gas at two closed waste disposal sites in Istanbul, Turkey, Journal of Scientific \& Industrial Research, 66, 403-406.

Park J. and Shin H. (2001), Surface emission of landfill gas from solid waste landfill, Atmospheric Environment, 35, 3445-3451.

Pichtel J. 2005. waste management practices,municipal,hazardous,industrial. Boca Raton, FL: Taylor \& Francis Group.

Sadeghi H., Zolfaghari M. and Heydarizade M. (2011), Estimation of Electricity Demand in Residential sector using Genetic Algorithm Approach, International Journal of Industrial Engineering \& Production Research, 22, 43-50.

Salehi S., Dehghanifard E., Jonidi Jafari A., Atafar Z., Farzadkia M., Ameri A. and Nabizadeh R. (2011), Qualitative Assessment of Compost Products of Tehran and Khomein Facilities, Iran, International Journal of Applied Environmental Sciences, 6, 81-86.

Stern J.C., Chanton J., Abichou T., Powelson D., Yuan L., Escoriza S. and Bogner J. (2007), Use of a biologically active cover to reduce landfill methane emissions and enhance methane oxidation, Waste management, 27, 1248-1258.

Tchobanoglous G., Tcheisen H. and Vigil S. (1993), Integrated solid waste management. New York: McGraw-Hill.

Themelis N. and Ulloa P. (2007), Methane generation in landfills, Renewable Energy, 32, 1243-1257.

Thompson S., Sawyer J., Bonam R. and Valdivia J.E. (2009), Building a better methane generation model: Validating models with methane recovery rates from 35 Canadian landfills, Waste management, 29, 2085-2091.

Tsatsarelis T. and Karagiannidis A. (2009), Estimation of future methane production from Hellenic landfills, Global Nest Journal, 11, 162-171.

US-EPA. 2005a. First order kinetic gas generation model parameters for wet landfills. In EPA-600/R-05/072. Washington, D.C.: United States Environmental Protection Agency.

US-EPA. 2005b. Landfill Gas Emissions Model (LandGEM) Version 3.02 User's Guide In EPA-600/R-05/047. Washington, D.C.: United States Environmental Protection Agency.

US-EPA. 2009a. LFG Energy Project Development Handbook. Washington, D.C.: United States Environmental Protection Agency.

US-EPA. 2009b. User's Manual Mexico Landfill Gas Model Version 2.0 Washington, D.C.: U.S. Environmental Protection Agency.

Wang-Yao K., Towprayoon S. and Chienchaisri C., 2006. Seasonal Variation of Landfill Methane Emissions from Seven Solid Waste Disposal Sites in Central Thailand In Joint International Conference on "Sustainable Energy and Environment (SEE 2006)". Bangkok Thailand.

Wangyao K., Yamada M., Endo K., Ishigaki T. and Naruoka T. (2010), Methane Generation Rate Constant in Tropical Landfill, Journal of Sustainable Energy \& Environment, 1, 181-184.

Zamorano M., Ignacio Pérez Pérez J., Aguilar Pavés I. and Ramos Ridao Á. (2007), Study of the energy potential of the biogas produced by an urban waste landfill in Southern Spain, Renewable and Sustainable Energy Reviews, 11, 909-922. 